JELTL (Journal of English Language Teaching and Linguistics) e-ISSN: 2502-6062, p-ISSN: 2503-1848

2019, Vol. 4(2)

www.jeltl.org

\title{
Revisiting PQ4R and CSR for Teaching Reading Skills for Adolescents
}

\author{
Ryan Oktarini \\ Yogyakarta State University, Indonesia \\ e-mail: ryanoktarini@gmail.com \\ Sugirin \\ Yogyakarta State University, Indonesia \\ e-mail:sugirin@uny.ac.id
}

\begin{abstract}
The developing technonolgy brings the teenagers to the world interaction without boundary. Teenagers, or adolescents, are demanded to be able to master English. Thus, teaching and learning reading skills has become one essential factor to help them to master English. The aims of this research are to find out the effectiveness of PQ4R and Collaborative Strategic Reading on students' reading skill development for adolescents; (2) to find out the most effective technique for teaching reading skill for adolescents. This study was a quasiexperimental research with two experimental groups and one control group. The three variables used were PQ4R, Collaborative Strategic Reading (CSR), and Conventional techniques. The sample of this study were grade X Science 1, X Social 1 and X Social 2 who had homogenous reading level who were selected by using Cluster Random Sampling. The quantitative data were collected by using pretest and posttest to assess the reading comprehension. The result indicated that there was a difference in the students' reading achievement given different treatment. Students taught using PQ4R had an improvement from 61.75 to 71.63 while students taught using CSR had improvement from 63.32 to 75.50 . Students taught using conventional technique also indicated improvement from 62.5 to 68.38. The most effective technique was CSR compared to PQ4R and Conventional techniques. The improvement of students' reading skill development reach $15.9 \%$ while the improvement using PQ4R was $19.25 \% 9$ and using conventional technique was 9.28\%.
\end{abstract}

JELTL (Journal of English Language Teaching and Linguistics), 4(2), 2019 
Ryan Oktarini \& Sugirin

Therefore, it can be concluded that CSR was the most effective technique for teaching reading skills for adolescents compared to $P Q 4 R$ and conventional techniques.

Keywords: Adolescents, CSR, PQ4R, Reading skill

\section{INTRODUCTION}

As technology is getting more developed, the closer and easier people meet and interact to each other from other countries. In this development, to be able to communicate, people need to use a language. All people need to master English to be able to speak to other people with different language. Acquiring language is a long-term process that need to be done from early age. Adolescent is a transition time from children to teenagers (Bongolan, Moir, \& Baron, 2010). Adolescent is the age between 13 to 19 years old (Lesiak, 2015). Therefore, they are demanded to master English. In this developing era, adolescents need to become proficient in speaking English since it is a universal langauge to be used to coomunicate throughout the world. However, to be able to speak, one should acquire reading skill first. Krashen as cited in (Hill \& Holden, 1995), argued that acquiring reading skills can contribute to the development of foreign language learning. Without having reading skills, they will meet a difficulty to speak as reading is a source for what one will say. To help the readers understand what they are reading, teaching reading skill should facilitate the learners as the readers.

There is no doubt that in the teaching and learning process of reading, the obstacles can be found anytime and anywhere. They can come from the teacher, the learners, the materials, or the learning process. However, the problems in this study that will be discussed are related to the adolescent learners and the reading activities. In more definite way, the problems are in the form of the learners' lack of vocabulary, low motivation of learners, and also the monotonous activities. The main point of learning is that both the teachers and the students must understand what they teach and learn. One of the problems is related to vocabulary. Students need to acquire many vocabulary with their meaning to be able to become good readers (Grabe, 2009). Here, Grabe emphasised that the students do not only know literal meaning but also contextual meaning of the words.

Besides lacking vocabulary, the difficulties of reading can also be caused by the teachers and learning process. In some cases, the teachers use a conventional teaching to deliver the materials. It is less interesting since adolescence is the time when teenagers are easy to be bored and distracted by other things. Sometimes, the teachers explain then ask the students to do some comprehensions exercise only. However, the success of learning is also affected by other factor namely the use of technique. Nunan (1999) argued that teaching technique contributes to the success of teaching. When the teachers want their students to master the reading skill, the teacher should also need to use teaching technique. The lack of teaching technique becomes one problem in reading comprehension for students (Nunan, 1999).

In order to help the students in their reading comprehension, the use of specific techniques is required. This study focused on the effectiveness of two reading techniques on 
grade X students' reading skills at Godean 1 Senior High School. The techniques are PQ4R and CSR (Collaborative Strategic Reading). However, to compare the result, the researcher also used a conventional technique. The first technique, PQ4R which stands for Preview, Question, Read, Reflect, Recite, Review, is proven to be an effective technique to teach reading. As stated by (Rathus, 2006), PQ4R encourages and supports the learners to be interested in the topic of discussion and at the same time, it requires the students to be proactive rather than reactive during the reading activities. A study conducted by Lailatis (2015) supports the effectiveness of PQ4R. The result of the research showed that the students' reading comprehension improve after using PQ4R in the learning process (Lailatis, 2015). Another research conducted by Fadlilatu (2018) showed that implementing PQ4R can improve the studnets' reading skills in comprehending the texts (Fadlilatu, 2018). A research on PQ4R which was conducted by Dwi, Iskandar, \& Yuliana (2018) also showed that this technique was an effective tool to improve the students' reading comprehension. Anizul (2015), in her research on PQ4R, argued that PQ4R creates a happy and engaging atmosphere during the teaching and learning process. Besides, this strategy also helps the students in improving their reading achievement. The second technique is CSR (Collaborative Strategic Reading). It is a reading technique which can also help the students in reading comprehension. It consists of several steps namely Preview, Click and clunk, Get the gist, and Wrap up. It is proven to help the students understand the reading text easily. It is strengthen by a research coducted by Dian Novita (2018) that Collaborative Strategic Reading was effective in improving the students' comprehension on reading texts compared to the control group. It is shown in the result of the posttest which has higher score that than in the pretest score (Novita, 2018). Another research was conducted by Denissa (2016) that showed the improvement in students' reading comprehension, especially in narrative text, taught using Collaborative Strategic Reading. The posttest result was higher than the pretest result. A research on CSR conducted by Riyawi (2018) showed that there was a significant effect on the reading comprehension after applying the Cpllaborative Strategic Reading.

Based on explanation above, conducting this research is necessary to find out the most effective technique for adolescent learners in their reading skills, especially in reading comprehension. It is expected to the students to be able to use the techniques during the teaching and learning activities or outside the class activities when they read texts.

\section{LITERATURE REVIEW}

Reading is defined by Johnson (2008). He stated that reading is the same as creating meaning and he also added that it is a practice of using texts to generate meaning. The meaningful reading activity is not only creating meaning, but also understanding the meaning (Johnson, 2008). It means that the students need to do reading comprehension. Reading comprehension is a process of connecting the ideas of the readers to the writers by using texts to get the meaningful interpretation (Rodli, 2015).

Comprehension means using context and prior knowledge to get the meaning of the reading text and adjust to what the readers listen and read (Israel \& Duffy, 2009). The readers need to activate their background knowledge so that they will not miss-interpret what they read. In some context, the readers need to know when to use literal meaning and contextual meaning in comprehending the texts. Reading is considered as personal activity 


\section{Ryan Oktarini \& Sugirin}

so that the readers need to use their own background knowledge to generate the meaning. (Israel \& Duffy, 2009)

However, teaching reading is not only giving some texts to be read by the learners. Riddell (2003) mentions several principles of teaching reading where the teacher needs to focus on helping the students to acquire the vocabulary, engage the students' interest, and also help in comprehending the text. Riddell (2003) also explains some steps to be followed in teaching reading. Firstly, by understanding the meaning of the vocabulary that will be used in the reading activities. This activity facilitates the students in mastering the vocabulary and using them in context. Secondly, it is by engaging the students to the topic. It is to attract the topic so that the students will be willing to interest and get involved in the discussion of the topic. Thirdly, it is by building the students' confidence. In doing this, the teacher can provide the students with the easier activities first. Then, the activities will be getting more complex. Even though the activities are getting more complex, the students still do not lose their confidence, since the teacher has built their confidence step by step. Fourth, it involves reading comprehension activities. In this stage, the teacher gives more reading comprehension activities so that the students can understand the content of the reading text. Lastly, follow-up activities are also important. The activity can be in the form of speaking. Students also need to speak up what they have read. Therefore, communicative reading activities are needed in the learning activities. It may lead the students to the next skills.

When teaching reading skills, teachers also need to consider who the learners or students are, since teaching reading to children, adolescents, adults is different especially teaching adolescent. Adolescent is the age from late children age to primary school level to high school level (Bongolan et al., 2010) and a transition age between childhood to adulthood (Crone, 2016). In teaching and learning process, it is a critical time when teenagers acquire the idea from different teachers with different ways. The definition of adolescent is also added by Lesiak (2015). Lesiak stated that adolescent is the age between 13-19 years old (Lesiak, 2015). Adolescence is a critical period where there teenagers can experience anxiety, eager anticipation of future, a sense of regret and psychological adjustment (Coleman, 2011). However, in teaching adolescent, the teachers need to go beyond the conventional teaching since adolescents spark when they are being engaged in the current trends and issues (Crawford, 2007). When teaching adolescent, teachers need to consider the cognitif differences by offering the scaffolding to avoid the adolescent frustation so that they will comprehend deeper on the unfamiliar topics (Karten, 2009).

Based on the explanation above, teachers should use some teaching techniques which can engage and facilitate the learners in acquiring the reading comprehension skill. There are two techniques which can be used by teachers namely PQ4R and Collaborative Strategic Reading. The first technique is PQ4R. PQ4R benefits the readers in helping them concentrating and formulating the information to make it meaningful (Slavin, 1997). PQ4R consists of several steps which help the students in understanding the text. Besides, the steps also teach them in many skills which are advantageous for them. Allen adds the benefits of PQ4R. By using this technique, the readers will be able to think deeply about the content of the texts for the main point of this technique is to help the readers in comprehending the text (Allen, 2008). The students as the readers also get the ideas by doing the step by step 
process. The strengths of using PQ4R are also explained by Hayes. By using this technique during teaching and learning activities, the students will get used to using it (Hayes, 1992). Therefore, the students can also use this technique when they read texts by themselves outside the teaching and learning activities. Eanest also strengthens the benefits of PQ4R. He states that one of the benefits of using PQ4R is helping the students in getting the meaningful information and helping them in getting the purpose of reading (Eanes, 1997).

The second technique which is proven to be effective in teaching reading for adolescent is Collaborative Strategic Reading (CSR). According to Vaughn\& Klingner, CSR is applied into two phases namely the strategies and the cooperative group (Vaughn \& Klingner, 1998). It means that this technique consists of two steps namely the strategies and the cooperative group. The strategies help the readers in getting the main point of what they read while the cooperative group helps the students in comprehending the text by discussing within the small groups. In cooperative group discussions, each member of the group has their own role such as the leader, the clunk expert, gist expert, and announcer. By having those roles, the students should be responsible to the task of each role. The strength of CSR is explained by Cohen\&Cowen. They state that the steps help the students to get the message and the idea from the text by working in small group and implementing the steps to get the information and the message (Cohen \& Cowen, 2008).

\section{RESEARCH METHODS}

The purpose of this study was to find out the effectiveness of PQ4R and Collaborative Strategic Reading compared to the conventional teaching technique and to find out which technique was the most effective one. This study was a quasi-experimental design. In this study, the two independent variables namely PQ4R and CSR and one dependent variable namely Reading Skills were analized and compared to find out the effectiveness.

\subsection{Population and Sample}

The population of this research was Grade X students at Godean 1 Senior High School. The researcher conducted the research in three classes namely X Social 1, X Social 2 , and X Science 1 which each class consists of 32 students. All students attended the class during the research. Therefore, the sample of this study was 98 Grade X students.

\subsection{Instruments}

This study used test as the instrument in gathering the data. The test was written test which consisted of 50 multiple choice questions. The questions were designed to assess the students reading comprehension. The test was used in the pretest and posttest. The pretest was given to the students before the treatment in each experimental class while the posttest was given to the students after the treatment in each class.

\subsection{Data Analysis}

Descriptive statistical and inferential analyses were used to analyze the data. Normality distribution and test of homogeneity of variance of the data were used. In analysing the normality distribution of the data, Kolmogorov-Smirnov was used using SPSS program. Levene test was used to analyse the homogeneity of the variance. Both analyses 


\section{Ryan Oktarini \& Sugirin}

used ANCOVA in SPSS program. To find out the effectiveness of the techniques, the researcher also used ANCOVA to compare the result of the data. In addition, to find out the effect of the pretest and the techniques to the result of the posttest, a test of BetweenSubjects Effects was conducted. The data analyses were used to answer the research questions as follows.

1. Is PQ4R technique more effective in improving students' reading skill development compared to conventional technique?

2. Is Collaborative Strategic Reading more effective in improving students' reading skill development compared to conventional technique?

3. Is PQ4R technique more effective in improving students' reading skill development compared to Collaborative Strategic Reading?

4. Which one is the most effective technique among PQ4R, Collaborative Strategic Reading, and conventional techniques in improving the students' reading skill development?

\section{FINDINGS}

The pretest and posttest data were analysed by using descriptive analysis. The data analysis consists of mean score and standard deviation. The data were as follows.

Table 1. The result of Descriptive Statistic

\begin{tabular}{llllc}
\hline & N & Sum & Mean & Std. Deviation \\
\hline Pretestcontrol & 32 & 2000.00 & 62.5000 & 5.40012 \\
Posttestcontrol & 32 & 2188.00 & 68.3750 & 4.23313 \\
PretestPQ4R & 32 & 1976.00 & 61.7500 & 4.83935 \\
PosttestPQ4R & 32 & 2292.00 & 71.6250 & 5.01450 \\
PretestCSR & 32 & 2026.00 & 63.3125 & 5.82784 \\
PosttestCSR & 32 & 2416.00 & 75.5000 & 6.36523 \\
Valid N (listwise) & 32 & & & \\
\hline
\end{tabular}

Based on the Table 1, the mean score of pretest and posttest in the control group were 62 and 68 while the value of the standard deviation were 5.4 and 4.2. However, the mean score of the pretest and posttest in the experiment group 1 were 61 and 71 with the standard deviations were 4.8 and 5.0. the experiment group 2 had 63 and 75 for the mean score while the standard deviations were 5.8 and 6.3.

After analysing the mean score, the data were analyzed by using ANCOVA. ANCOVA test was conducted to find out the effect of pretest and technique in the students' test result. A test of Between-Subjects Effects was conducted in order to find out the effect. Table 2. Percentage of the pretest in CSR group

\begin{tabular}{cccccc}
\hline Source & $\begin{array}{c}\text { Type III Sum } \\
\text { of Squares }\end{array}$ & Df & $\begin{array}{c}\text { Mean } \\
\text { Square }\end{array}$ & F & Sig. \\
\hline Corrected Model & $2470.640^{\mathrm{a}}$ & 3 & 823.547 & 81.060 & .000 \\
Intercept & 351.448 & 1 & 351.448 & 34.592 & .000 \\
pretest & 1656.307 & 1 & 1656.307 & 163.027 & .000 \\
Technique & 679.012 & 2 & 339.506 & 33.417 & .000 \\
Error & 934.693 & 92 & 10.160 & & \\
Total & 498768.000 & 96 & & & \\
Valid N (listwise) & 32 & & & & \\
\hline
\end{tabular}


The Sig. value of the technique is 0.000 . It means that the Null Hypothesis was rejected. Therefore, there was a significant difference between students who were taught by using different techniques. Besides, the Sig value in the Corrected Model shows 0.000. It means that both the pretest and the techniques affect the result of students' achievement. Below were the hypotheses of the research.

\section{Hypothesis 1}

The first hypothesis of the research was as follow:

Ha1: There is a significant difference in the students' reading skills among students who are taught using PQ4R and those who are taught using conventional teaching technique.

Table 3. Multiple comparison of PQ4R and Conventional techniques in the posttest score.

\begin{tabular}{llcccc} 
& & Mean & \multicolumn{3}{c}{$95 \%$ Confidence Interval } \\
& Difference & & Lower & Upper \\
(I) Techniques & (J) Techniques & (I-J) & Std. Error & Bound & Bound \\
PQ4R & CSR & $-3.87500^{*}$ & 1.31957 & .013 & -7.0922 \\
& Conventional & $3.25000^{*}$ & 1.31957 & .047 & .0328 \\
\hline
\end{tabular}

*. The mean difference is significant at the 0.05 level.

Based on Table 3 above, the Mean Difference between PQ4R and Conventional was 3.2. meanwhile, the Sig. value between PQ4R and Conventional was 0.047. It was less than 0.05. therefore, it meant that there is a significant difference between PQ4R and conventional techniques.

\section{Hypothesis 2}

The second hypothesis of the research was as follow:

Ha2: There is a significant difference in the students' reading skills between students who are taught using CSR and those who are taught using conventional teaching technique.

Table 4. Multiple comparison of CSR and Conventional techniques in the posttest score.

\begin{tabular}{llcrcc} 
& \multicolumn{3}{c}{ Mean } & & \multicolumn{2}{c}{$95 \%$ Confidence Interval } \\
& Dower & Upper \\
(I) Techniques & (J) Techniques & $(\mathrm{I}-\mathrm{J})$ & Std. Error & Bound & Bound \\
CSR & PQ4R & $3,87500^{*}$ & 1,31957 &, 013 & .6578 \\
& Conventional & $3.25000^{*}$ & 1.31957 & .047 & .0328 \\
\hline
\end{tabular}

*. The mean difference is significant at the 0.05 level.

Table 4 showed the significance level between CSR and Conventional. The Sig. value was 0.00 . The sig. value was lower than 0.05 . the mean difference between CSR and conventional was 7.1. It can be concluded that there was a significant difference between CSR and conventional techniques.

\section{Hypothesis 3}

The third hypothesis of the research was as follow:

Ha3: There is a significant difference in the students' reading skills between students who are taught using PQ4R and those who are taught using CSR 
Ryan Oktarini \& Sugirin

Table 5. Multiple comparison of CSR and PQ4R techniques in the posttest score.

\begin{tabular}{llcrrr} 
& & Mean & & \multicolumn{2}{c}{ 95\% Confidence Interval } \\
& & Lower & Upper \\
(I) Techniques & (J) Techniques & (I-J) & Std. Error & Bound & Bound \\
CSR & PQ4R & $3,87500^{*}$ & 1,31957 &, 013 & .6578 \\
& Conventional & $3.25000^{*}$ & 1.31957 & .047 & .0328 \\
\hline
\end{tabular}

*. The mean difference is significant at the 0.05 level.

In the Table 5, the mean difference was 3.8. The sig. value between CSR and PQ4R was 0.13 . Since the sig. value was higher than 0.05 , it can be concluded that there was a significant difference between CSR and PQ4R techniques.

\section{Hypothesis 4}

The fourth hypothesis of the research was as follow:

Ha3: There is a technique which is the most effective technique among PQ4R, CSR, and conventional teaching techniques for teaching and learning reading for adolescents.

Table 6. The result of Descriptive Statistic

\begin{tabular}{lcccc}
\hline & N & Sum & Mean & Std. Deviation \\
Pretestcontrol & 32 & 2000.00 & 62.5000 & 5.40012 \\
Posttestcontrol & 32 & 2188.00 & 68.3750 & 4.23313 \\
PretestPQ4E & 32 & 1976.00 & 61.7500 & 4.83935 \\
PosttestPQ4R & 32 & 2292.00 & 71.6250 & 5.01450 \\
PretestCSR & 32 & 2026.00 & 63.3125 & 5.82784 \\
PosttestCSR & 32 & 2416.00 & 75.5000 & 6.36523 \\
Valid N (listwise) & 32 & & & \\
\hline
\end{tabular}

Table 6 showed the mean score of the pretest and posttest in the control group and experiment groups. The mean of the pretest and posttest in the control group were 62.5 and 68.3. There was an improvement in the students' reading skills to $9.28 \%$. the result of the mean score of teh pretest and posttest in the experiment group 1 were 61.75 and 71.62 which it improves to $15.9 \%$. In the CSR group, the mean score of the pretest and posttest were 63.3 and 75.5. It improved to $19.25 \%$.

\section{DISCUSSION}

According to the result of the research, all three techniques have their effectivness. It can be seen from the result of the pretest and posttest. Each group has improvement in the score of the test.

Based on the finding, there are some points that can be concluded. Firstly, the first technique, PQ4R, has several steps which are proven to be effective in helping the students comprehensing the text. Harmer (2001) says that reading requires some process as identifying the topic, predicting and guessing, reading and listening for general understanding, reading and listening fot specific information, reading and listening for detail information, and interpreting texts.. It is in line with the steps of PQ4R. Therefore, the implementation of PQ4R is suitable with the process of reading. Each process of PQ4R represents the reading process which can enhance the students' comprehension of the text. 
There are some differences in the result of the pretest and posttest in the PQ4R group. Especially, the use of PQ4R technique is more effective compared to conventional technique. From the posttest result, the students' achievement in the PQ4R group increases to $15.9 \%$. There is also improvement in the control group. The improvement reaches to 9.28\%. Based on the result of improvement, it can be concluded that PQ4R is more effective than conventional technique. The finding of this research supports the result of resaerch conducted by Al-Qawabeh \& Aljazi (2018) that there is a significant difference of in the students' reading comprehension taught using PQ4R and conventional technique since this technique gives step by step process which can ease the students in understanding the text. The students taught using PQ4R show more comprehension in reading texts.

The foundation of PQ4R is focusing on the orgnizing the information through the steps to make it more meaningful (Carter, 2013). The findings on this research was that PQ4R is more effective than conventional teaching technique. Therefore, the findings of this research were in line with the PQ4R definition stated by Carter. Through step by step process using the strategies in comprehending the reading texts, the students found it easier to get the main idea of the reading texts.

Secondly, compared to conventional technique, CSR is more effective to be applied in teaching reading. The improvement in the mean score of the CSR group is $19.25 \%$ while in the control group is only $9.28 \%$. This finding also supports a research conducted by Rini Septiani In 2016. The research found that Collaborative Strategic Reading is an effective technique in improving the students' reading comprehension (Septiani, 2016). Another research on Collaborative Strategic Reading was conducted by Indah (2015). The result of the research showed that the reading proficiency of the students improved after given the treatment.

The results of this research also strengthen the theory by Klingner as cited in Feng (2013). Klinger defined Collaborative Strategic Reading as an engaging way of comprehending the reading text by breaking down the information to become more comprehensible and by working in a small group discussion using a set of cue card to help the students in understanding the information of the texts (Feng, 2013). Based on the definition above, this research showed the same main point that is the students' reading comprehension taught using CSR is better than those taught using conventional technique.

However, among all those three, the most effective technique to be applied for teaching reading skills for adolescent is Collaborative Strategic Reading (CSR) for it is proven in the result of the posttest. The collaborative activities might help the adolescent learners to lessen their anxiety and frustation when they were in the learning difficulty. It is as Coleman (2011) said that adolescent is the time when the teenagers may face anxiety, eager anticipation of future, a sense of regret and psychological adjustment. Therefore, applying CSR in the teaching reading will give great positive achievement for the students. However, it is also possible to apply other technique, PQ4R, during reading activities, for it also helps the students improving their reading comprehension skill.

In summary, the main focus on this research was to find out the most effective technique to be applied during the teaching reading skills especially reading comprehension for adolescent. The application of PQ4R and CSR had some effects in the students' reading skills which both techniques could improve their reading comprehension. 
Ryan Oktarini \& Sugirin

\section{CONCLUSION}

Based on the finding and discussion, it can be concluded that there was improvement in the adolescent students when they were taught using PQ4R, CSR, and conventional techniques. However, among those three techniques, CSR was the most effective technique compared to PQ4R and conventional techniques. Both techniques have positive effect with different level of effectiveness for the students. Therefore, the teachers may choose the best or most appropriate and applicable technique to be applied in the teaching reading. Based on the research result, the teacher may use the most effective technique. However, the teacher should also consider the students' condition in choosing the techniques. It may be possible to apply PQ4R and conventional technique, since it also showed improvement in the research result even though it is less significant.

\section{REFERENCES}

Al-Qawabeh, R. H., \& Aljazi, D. A. A. (2018). The Effectiveness of Using PQ4R Strategy in Teaching Reading Comprehension in Arabic Language Subject among Ninth Grade Students' Achievement in Jordan. World Journal of Educational Research. https://doi.org/10.22158/wjer.v5n2p159

Allen, J. (2008). More tools for teaching content literacy. New York: Stenhouse Publishers. Anizul, F. (2015). Teaching reading narrative text through PQ4R (Preview, Question, Read, Reflect, Recite, Review) strategy. Walisong State Islamic University.

Bongolan, R., Moir, E., \& Baron, W. (2010). Keys to the Seondary Classroom: A Teacher's Guide to the First Months of School. California: Corwin Press.

Carter, C. E. (2013). Mindscapes: critical reading skills and strategies. Boston: Cengage Learning.

Cohen, V. L., \& Cowen, J. E. (2008). Literacy for children in an information age: teaching reading, writing, and thinking. Belmont: Thomson Wadsworth.

Coleman, J. C. (2011). The Nature of Adolescent 4th Edition. London: Routledge.

Crawford, G. B. (2007). Brain-Based Teaching With Adolescent Learning in Mind. Retrieved from https://books.google.co.id/books?id=f7HYR1\%5C_7RwUC

Crone, E. A. (2016). The Adolescent Brain: Changes in learning, decision-making and social relations. Retrieved from https://books.google.co.id/books?id=i5uuDQAAQBAJ

Denissa, F. P. (2016). The Effectiveness of Collaborative Strategic Reading (CSR) in Improving Students' Reading Comprehension in Narrative Text. Universitas Pendidikan Indonesia.

Dwi, E. M., Iskandar, A., \& Yuliana. (2018). The effect of using PQ4R (Preview, Question, Read, Reflect, Recite, Review) strategy on EFL students' reading comprehension chievement. Research in English and Education, 3(1).

Eanes, R. (1997). Content Area Literacy: Teaching for Today and Tomorrow. New York: Delmar.

Fadlilatu, L. (2018). The effectiveness of pq4r strategy to improve students' reading comprehension of report text for ninth year students of smp $n 2$ banyubiru in the academic year 2017/2018. IAIN Salatiga. 
Revisiting PQ4R and CSR for Teaching Reading Skills for Adolescents

Feng, J. (2013). Teacher as researcher: action research by elementary teachers. Morrisville: Lulu Press.

Grabe, W. (2009). Reading in a Second Language: Moving From Theory To Practice. In The Role of Ethics in International Law.

Harmer, J. (2001). The practice of English language teaching 3rd Edition. New York: Longman.

Hayes, D. A. (1992). A sourcebook of interactive methods for teaching with texts. Massachusetts: Allyn and Bacon.

Hill, D., \& Holden, S. (1995). Language Teaching: 1988 Milan Conference. London: Modern English Publication.

Indah, F. R. (2015). The implementation of collaborative strategi reading and its effect on students' reading comprehension. UIN Alauddin Makassar.

Israel, S. E., \& Duffy, G. G. (2009). Handbook of research on reading comprehension. New York: Routledge.

Johnson, A. P. (2008). Teaching reading and writing. New York: Rowman and Littlefield Education.

Karten, T. J. (2009). Inclusion Strategies That Work for Adolescent Learners! Retrieved from https://books.google.co.id/books?id=oTc4DQAAQBAJ

Lailatis, S. (2015). The application of pq4r (preview, question, read, reflect, recite, review) strategy to improve students" reading comprehension of the eighth years students of MTs NU Salatiga in the academic year 2015/2016. IAIN Salatiga.

Lesiak, K. (2015). Teaching english to adolescents. World Scientific News, 242, 246-260. Retrieved from http://www.worldscientificnews.com/wpcontent/uploads/2015/06/WSN-7-2015-246-260.pdf

Novita, D. (2018). Collaborative strategic reading (csr): an attractive strategy for teaching reading skill. Advances in Social Science, Education and Humanities Research, 125, 98-102.

Nunan, D. (1999). Second Language Teaching and Learning. New York: Heinle\&Heinle Publisher.

Rathus, S. A. (2006). Childhood and adolescence: Voyages in development. Childhood and Adolescence: Voyages in Development.

Riddell, D. (2003). Teaching English as a foreign language. London: Hodder Headline Ltd.

Riyawi, M. R. (2018). The effect of applying Colaborative Strategic Reading (CSR) towards students' reading comprehension at the eightth grade of MTs Hubbulwathan Duri. AlIshlah: Jurnal Pendidikan, 10(1).

Rodli, M. (2015). Applaying PQ4R strategy for teaching reading. Indonesia EFL Journal.

Septiani, R. (2016). The effectiveness of collaborative strategic reading (csr) towards the reading comprehension of the first grade students of sman 14 pekanbaru. Universitas Riau.

Slavin, R. E. (1997). Educational psychology theory, research, and practice 5th Edition. Massachusetts: Pearson Education, Inc.

Vaughn, S., \& Klingner, J. K. (1998). Teaching reading comprehension through collaborative strategic reading. Intervention in School and Clinic, 34, 284-292.

JELTL (Journal of English Language Teaching and Linguistics), 4(2), 2019 